\title{
AFRIKAI BESZÉLŐ DOBOK
}

\author{
BRAUER-BENKE JÓZSEF
}

Amíg a résdobok fö elterjedési területének a Kongó-medence és környezete tekinthetö, addig Nyugat-Afrika területén a térségben alkalmazott, hírközlő funkciójában konkurensnek tekinthető membranofon (a hang egy kifeszített membrán megszólaltatása által keletkezik) „,beszélő dob” típusok a jellemzőek. Nyugat-Afrikának nevezzük a szubszaharai övezet nyugati részét Gabon központtal, illetve a Guineai-öböl partvidéki országait, továbbá a nyugat-afrikai szavanna övezet elnevezése Nyugat-Szudán (az arab bilád asz-szudán 'feketék földje' elnevezés alapján) amely régióba tartozik Burkina Faso, Csád, Kamerun északi területe, Mali, Mauritánia déli területe, Niger, Nigéria északi területe és Szenegál.

Mivel az európai doboktól eltéröen a nyugat-afrikai térség dobtípusai többféle funkcióban is használatosak, ezért olyan vélemények is megfogalmazódtak, hogy az afrikai dobok mindegyike „beszélő dobnak” tekintheto” (Akpabot 1975: 36). Habár ez a megállapítás egy komparatív áttekintés szintjén nem állja meg a helyét, mert Dél-Afrikában egyáltalán nem terjedtek el a dobnyelvek, viszont Nyugat-Afrikában valóban több dobtípust is használnak „,beszélő” dobként és a dobnyelv felhasználása szélesebb körü, mint pusztán a hírközlő funkció. Egyebek között ezzel hívják össze a falutanácsot, küldenek üdvözletet a fönöknek vagy egy barátnak, búcsúztatják a még hallótávolságban járó vendéget vagy a lenyugvó napot, tudósítanak a sikeres vadászat eredményéről vagy közérdekủ munka állásáról, dobnyelven keresik az erdőben eltévedteket, figyelmeztetnek idegenek közeledésére, tüzesetre és más veszélyekre (Clarke 1934: 42). Ezen túlmenően a beszélő dobok a születés, menyegző, haláleset és egyéb társadalmi esemény alkalmából úgyszintén szerepet kaptak és bár a dobok kezeléséből a nőket kizárták, de az üzeneteket ők is megérthették, vagyis a beszélö dob egyszerre szólt a falu minden lakójához. Ehhez szükséges a szubszaharai Afrika nyelveinek tonális (egy-egy szótag kiejtésének hangmagassága, illetve annak változása jelentés-megkülönböztető szereppel bír) és holofrasztikus (egyszavas kifejezések, melyek részben egész közléseket kódolnak) jellege (Keszthelyi 1980: 581). A dobnyelv a beszéd olyan lényeges elemeit adja vissza, mint a magánhangzók és azok pontos zenei fekvése, a mássalhangzók közbeékeltségének a helye (rendszerint egy keményebb csengésủ fémeszközzel) és az üzenet szótagszáma. Mint például Ghána délnyugati részén az akan népek közé tartozó asante népcsoport körében elterjedt atumpan lábasdob típusa, amelynél az elefántcsontból készült kalapács 
alakú dobverővel a magánhangzókat (tkp. csak a zenei fekvésüket) ütik ki és a férfinak megfelelö, mélyebb hangú nagyobb dob membránjára erősített vasdarab ritmusa adja ki a mássalhangzókat (Kyerematen 1964: 60). ${ }^{1}$ (1. kép) Az atumpan dobokat a fontomfrom elnevezésủ asante királyi dobzenekarokban is alkalmazták, olykor még felvonulásokon hordozva is azokat (Marcuse 1975: 157). (2. kép) Az atumpan dobtípus változatai a szomszédos népek körében is megtalálhatóak, mert az adangbe nyelvủ ewe népcsoport atukpani és az asante népcsoporthoz hasonlóan az akan csoporthoz tartozó, Ghánából származó, de Elefántcsontpartra átköltöző baule népcsoport atungblan dobja egyértelmüen rokonítható az atumpan dobtípussal (NGDMI 1.1984: 83-84).

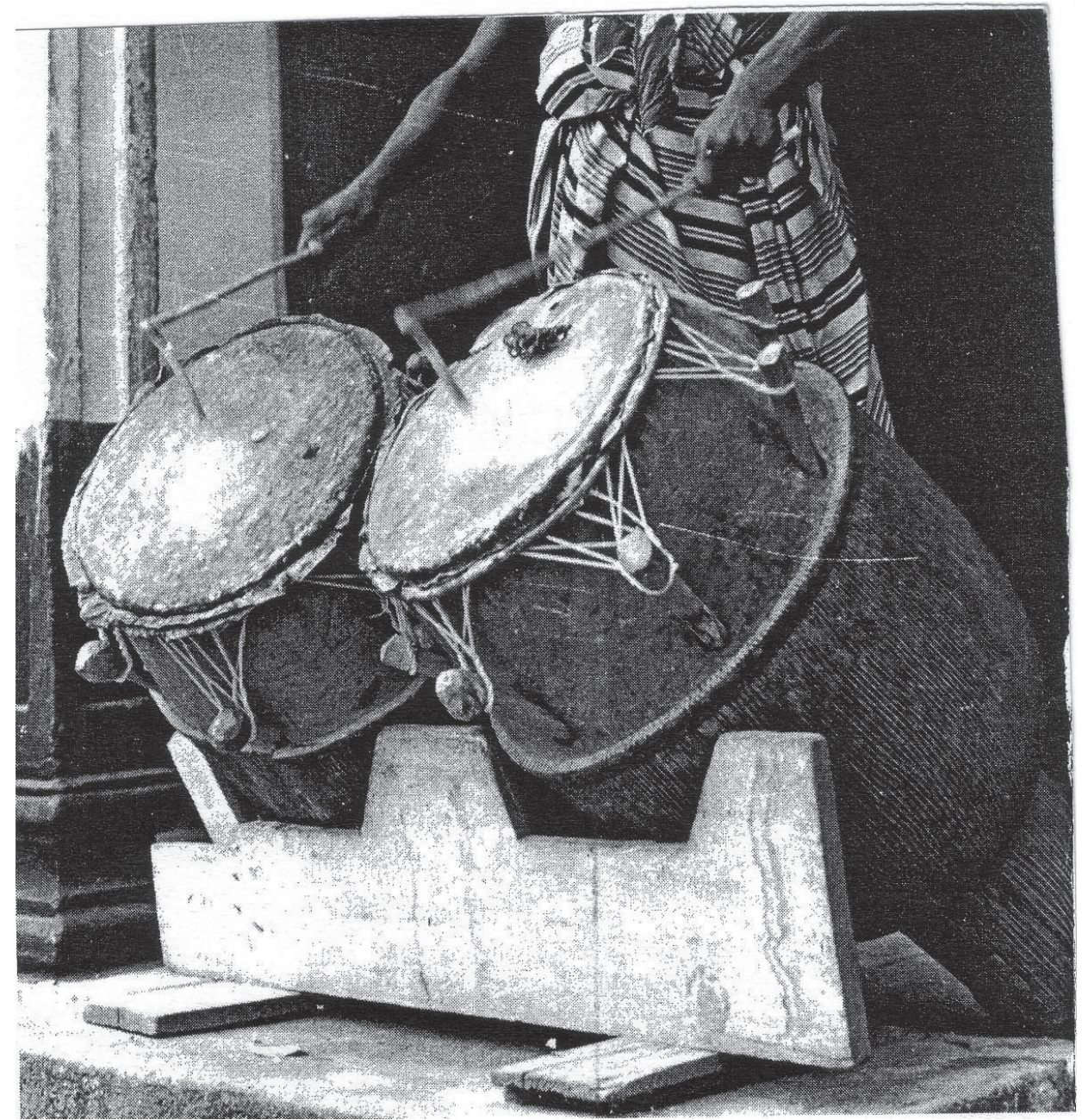

^1. kép. Atumpan beszélö dob Ghána (Kyerematen 1964 nyomán) 
A dobnyelv elöadásánál problémát jelentett, hogy a dobnyelvben megszaporodhattak a homofóniák (együtthangzás), mivel a dobok valójában nem reprodukálták magukat a magánhangzókat, csupán a zenei fekvésüket, a tónusukat jelezték, így a dobnyelvben az is rokon hangzású lehetett, ami az élőbeszédben nem volt az (Keszthelyi Tibor 1980: 582). Emiatt az értelemzavaró egybeesések elkerülésére a dobnyelv használói a költői körülírás eszközével éltek és a dobnyelvi megfogalmazás az élő beszédnél mindig terjedelmesebb volt.

Az információközlés mellett, a párosával használt atumpan dobokkal (a nagyobb-mélyebb dob a férfit ,atumpan nini”, míg a kisebb-magasabb dob a nőt „atumpan bereع" szimbolizálta) az asante dobosok költői formákat is megjelenítettek az „adowa” szertartás kíséreténél, ahol a dobos a múfaj szigorú szabályai szerint bemutatkozott, különféle megszólításokat alkalmazott. Ennek során az invokációját kiterjesztette a dob membránjára, a membránfeszítő ékekre, a már elhunyt neves dobos ősökre és mivel a dob membránja elefántfülből készült, a dobos az elefánt és a hangszertest alapjául szolgáló „tweneboa” fa (Cordia millenii) szellemét is megszólította és csak utána fogott hozzá a konkrét alkalomhoz kapcsolódó kommunikáció közléséhez (Kyereman 1964: 60). Ehhez kapcsolódóan még a fa kivágása előtt italáldozatot mutattak be a fa szellemének és imádkoztak hozzá, hogy ne dühödjön meg az őt ért sérelem miatt, amit a fa kivágásával okoztak (Nkeita 1966: 192).

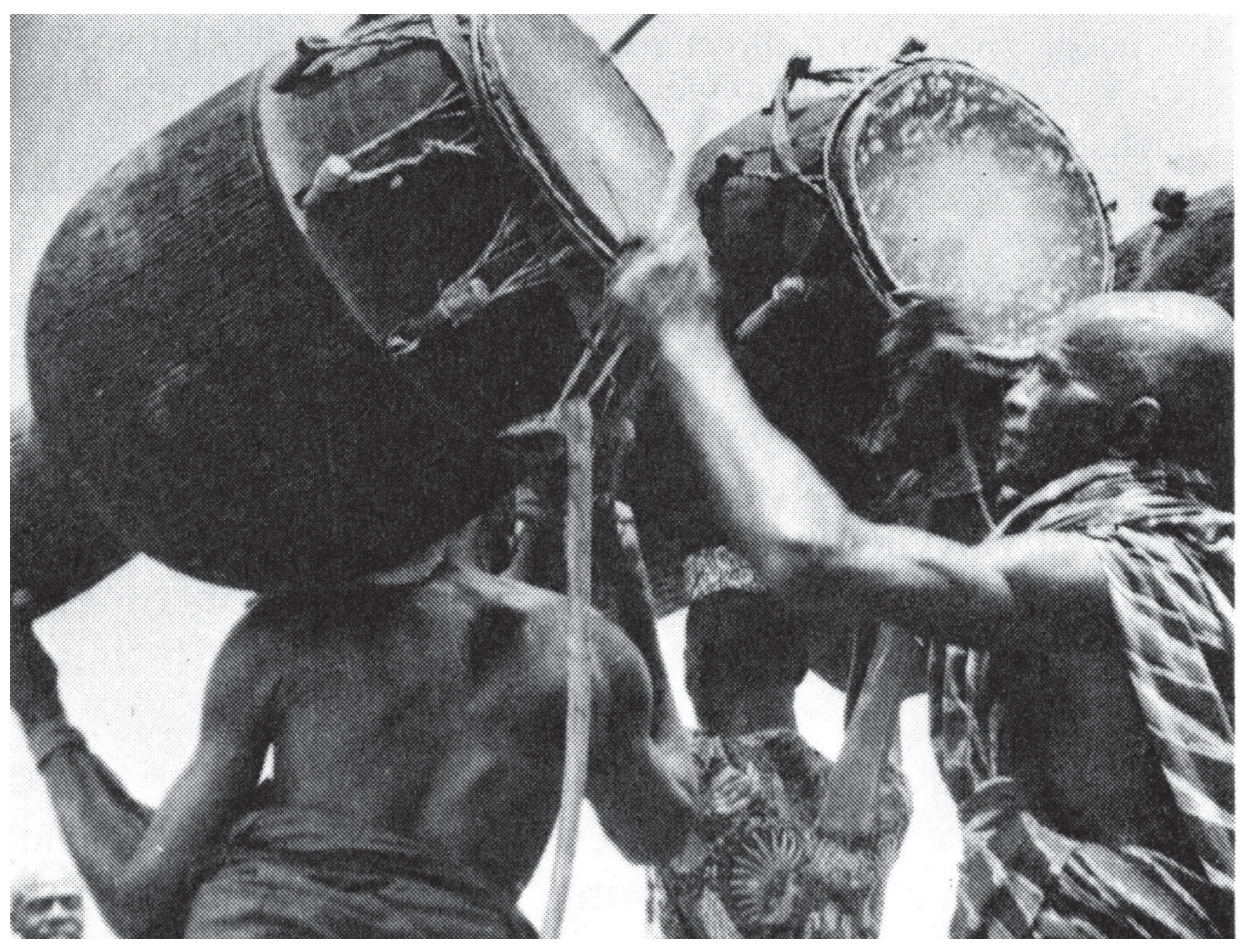

^ 2. kép. Fontomfon királyi dobok Ghána (NGDMA 1984 nyomán) 
Szintén a dobnyelv költői stíluseszközei közé tartoztak az élőlények, tárgyak és jelenségek állandósult dobnevei, amelyek a homofóniák miatti félreértések kiküszöbölésének és a könnyü érthetőségnek az esztétikummal párosuló igénye miatt alakulhattak ki. A dobnevek vizsgálata alapján felvetődik annak a lehetősége, hogy a költői érzék párhuzamosan alakulhatott a dobnyelvben és az orális költészetben, vagy éppen fordítva, és a dobnyelv inspirálhatta az orális költészetben ezt a költői beszédmódot (Keszthelyi 1980: 584-585). A dobnevekhez hasonló fogalmazású dicsérők és költői eszközök azonban nemcsak az Egyenlítői Afrika térségében, hanem Dél-Afrikában is elterjedtek, ahol viszont nem találtak dobnyelveket. Ezért ha valóban helytálló a feltételezés, miszerint a dobnyelvek és a szubszaharai Afrika tonális nyelveinek orális hagyományai direkt összefüggésbe hozhatóak egymással, akkor ennek alapján a Niger-kongói nyelvekkel együtt a DélAfrikában is megtelepedő bantu nyelvü népcsoportokkal a dobnyelvek is elterjedtek volna, tehát a résdobok dobnyelveit is beleértve a különböző dobnyelvek csak a bantu expanzió utolsó, 9. századi szakasza után alakulhattak ki és terjedhettek el az Egyenlítői Afrika térségében (BrauerBenke 2018: 140). Amennyiben helyes ez a feltételezés, a dobnyelvek akár ezer éven át is funkcionálhattak üzenetközvetítő szerepkörben az Egyenlitôi Afrika térségében. Viszont már az 1970-es évek vizsgálatai alapján kimutatható volt, hogy az elektrotechnikai kommunikáció megjelenésével az üzenetközvetítő dobok jelentősége erősen csökkent és ilyen funkciójú használatuk három generáció alatt gyorsan visszaszorult (Ong 1977: 427-428). Az Egyenlítői Afrika térségén belül Közép-Afrika északi részére, Szudán déli területére, Kamerun és a Kongó-medence jelentős részére jellemző, hogy a résdobokat nem fogalom rendszerü üzenetközvetítésre használják, hanem az emberi beszédhez hasonló, bővebb információs tartalmak megjelenítésére (Carrington 1949: 28). Ami felveti annak a lehetőségét, hogy ezen a kontaktzónának is tekinthető területen találkozott össze egy, az Egyenlítő keleti térségéből (Dél-Amerika, Óceánia, Délkelet-Ázsia) 
érkező, résdobokkal továbbított, fogalom rendszerü kommunikációs forma és egy Nyugat-Afrikára jellemző, membranofon dobokkal az emberi beszédet imitáló kommunikációs forma.

Szintén a beszélő dobok közé sorolható a Ghána, Togó és Benin területén élő ewe népcsoport atsimevu elnevezésű hordó dobja, amit egy „vudetsi” elnevezésủ állvány segítségével, derékszögben megdöntve szólaltatnak meg (Pantaleoni 1972: 53). Az állványra azért volt szükség, mert a dob hossza nem tette lehetővé, hogy függőlegesen felállítva a dobos elérje a membránt. Az atsimevu hordódob membránja antilop börből készül, amit egy növényi anyagból sodrott kötéllel és fapeckekkel rögzítettek a hangszertesthez. A „tsotsi” elnevezésű fapeckek a helyi „kpafia” fából készülnek és a megfeszítésükkel, illetve a meglazításukkal a membrán-feszesség finomhangolása is beállítható. Az atsimevu beszélő dobot sajátos játéktechnikával szólaltatták meg, mert a jobb kézben tartott ütővel és a balkéz tenyerének, illetve az ujjak kombinációjának változtatgatásával játszottak, attól függően képezve a hangot, hogy a membrán melyik részét ütötték meg (Jones 1959: 67). Ezzel a technikával három alaphangot képeztek. A „Ga” alaphangot a membrán közepét megütve a „Gi” hangot a megütött membrán rezgését a bal kéz ujjainak nyomásával képezve, és a „Ki” hangot a „Gi” hang képzéséhez hasonló módon a tenyér és az ujjak megfelelő helyzetủ membrán nyomásával, de a „Gi” hangnál magasabb hangot képezve játszottak. A három alaphang kombinációjával nyolc vokális szótagot tudnak képezni, úm. de, te, ge, tsi, to, $k a$, $d z a$, és $d z i$ (Jones 1959: 67). Amennyiben együttesben alkalmazták, az atsimevu 'nagyapa' vezető szerepü dobtípus volt, míg a kagan 'gyermek' vagy 'öcs' elnevezésủ dob az alapritmust játszotta összhangban az idiofon kísérö hangszerekkel, és a kidi az 'anya' dob aktívabb szerepet töltve be zenei válaszokat adott a nagyobb sogó 'apa' dobnak (3. kép). A nyugat-afrikai hordódob típusok a rabszolgakereskedelem által kerültek a Karib-térségbe, ahol az európai dobok fémből készült, csavaros membránfeszítési módozatait felhasználva alakították ki a latin-amerikai tánczene jellegzetes conga (konga) dobtípusait.

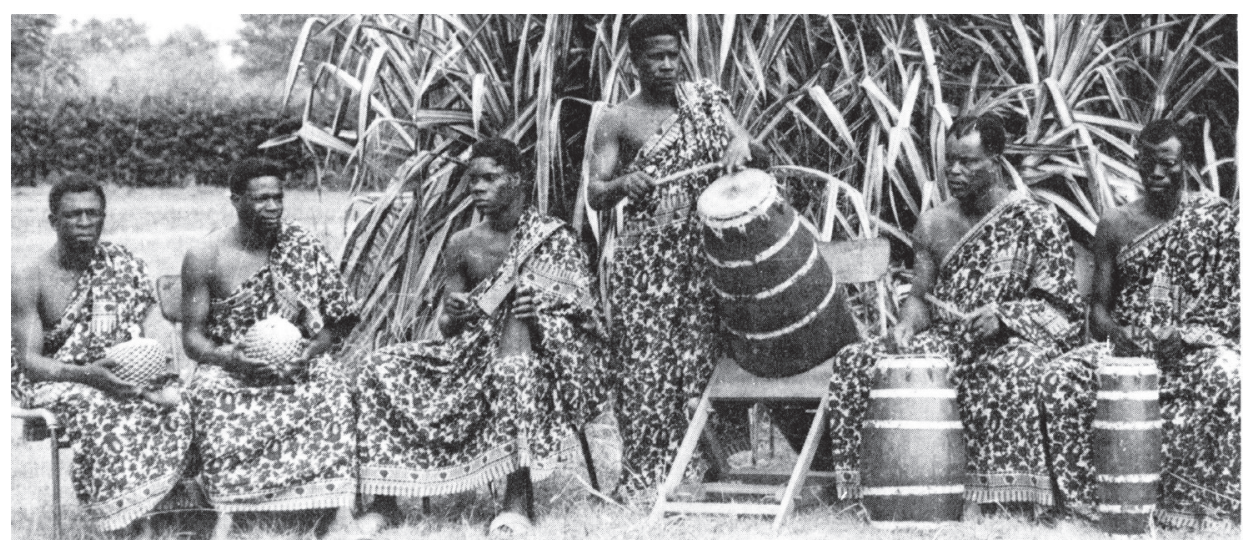

\3. kép. Atsimevu beszélö dob együttesben Ghána (Jones 1959 nyomán) 
Ami a nyugat-afrikai dobnyelvek eredetét illeti, a téma még korántsem feltárt és a témakörben történő korábbi komparatív munkák nyitva hagyták a kérdést (Carrington 1944: 75). Egy hipotetikus felvetés szerint a dobnyelvek talán összefüggésbe hozhatóak a Kanári-szigetek már kihalt őslakóinak a guancso népcsoport fütty-nyelvével, amelynek egyik variánsa napjainkig fennmaradt La Gomera szigetén (Marcuse 1975: 156). A már 1402-ből adatolhatóan ismert, a spanyolok által El Silbo-nak nevezett fütty-nyelv jelentés-megkülönböztető elemei a bizonyos hangmagasságú és hosszúságú füttyök, amelyekben két magánhangzót és négy mássalhangzót különböztetnek meg, több variánsban a hangmagasság és hangerősség váltakozásának megfelelően. A fütty-nyelv pontos eredete sem egyértelmü, de vannak olyan elképzelések, miszerint az Atlasz-hegység néptörzsei hozták magukkal a Kanári-szigetekre a mai Marokkó területéröl (Busnel 1976: 9-10). Ezért nem kizárt, hogy a dobnyelv egy hangszereken is előadható, tonalitásra alapuló közlésforma, ami jelen esetben egy dobtípuson van megjelenítve (Herzog 1934: 454). A kultúrakutatások egyértelmüen igazolták, hogy az észak-afrikai területekről (és vice versa) nagy számban kerültek át anyagi és kulturális javak a szubszaharai régióba (McCall 2008: 28). Ezért nem kizárt, hogy az emberi beszédet megjelenítő hangszertípus vagy annak az ötlete a Szaharán túlról érkezhetett a nyugat-afrikai régióba.

Szintén a „beszélő dobok” típusába sorolható, a formája után homokóra dobnak nevezett hangszertípus, amelynek az eredete a soninké és manding nyelvü Ghána vagy Wagadu Birodalom (790-1240) idejére vezethető vissza, ahol a griot (grió) zenészek kasztja használt ilyen hangszereket, amelyek a hausa népcsoport által a benini és a nigériai yoruba és a ghánai dogamba (dagomba) népek között is elterjedtek (Charry 2000: 229-234) (4. kép). A nyugat-afrikai száhel- és a szavanna-övezetének
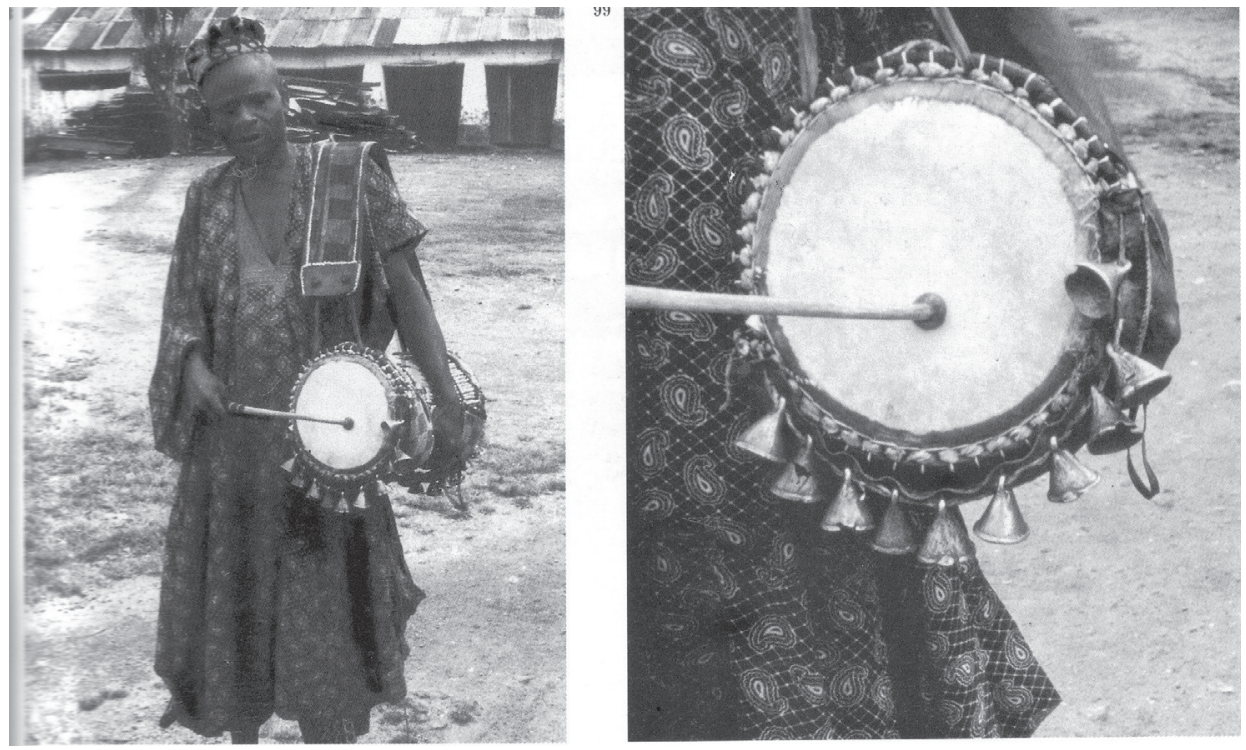

4. kép. Dundun beszélö homokóra dob Nigéria (Kubik 1989 nyomán) 
államaiban tevékenykedő griot (grió) zenész kaszt tagjainak az uralkodók vagy nemesemberek szolgálatában a történelmi hagyományok, eredetmondák, uralkodói és más előkelő családi genealógiák megjegyzése és továbbhagyományozása volt a feladata, amit ének- vagy zenekísérettel adtak elö. Egyéb elnevezései a különbözö népcsoportoknál: moor iggio, wolof guewel/géwél, fulbe mabo/gawlo, mandinka jali, maninka és bamana jeli, soninké geseré/jaaré, songhay jeseré, és hausa marok'i (Hale 1997: 251). A Néprajzi Múzeum „Afrika Gyüjteménye” (NMAGy) és a Weltmuseum Wien „Afrika südlich der Sahara” (WWAsS) gyüjteménye hangszereinek vizsgálata alapján a membrán feszességét zsinórzattal szabályozható homokóra dobtípus elterjedéséről Észak- ${ }^{2}$ és Nyugat-Afrikából ${ }^{3}$ vannak adataink. Ez utóbbi régióból Szenegambia ${ }^{4}$, Libéria ${ }^{5}$, Togó ${ }^{6}$, Egyenlítői-Guinea ${ }^{7}$ és Kamerun ${ }^{8}$ területéről. A legnagyobb hangszereket tartalmazó internetes adatbázis a MIMO (Musical Instruments Museums Online) adatai alapján ez még kiegészíthető Ghána és Nigéria területéről származó, zsinórzattal szabályozható homokóra dobtípus adatokkal. ${ }^{9}$

Mivel a zsinórzattal szabályozható membrános homokóradob típusok a TávolKeleten, Délkelet-Ázsiában és Nyugat-Afrikában egyaránt elterjedtek, már korábban felvetődött annak a lehetősége, hogy a zsinórral szabályozható indiai homokóradob típusok rokoníthatóak a nyugat-afrikai homokóradob típusokkal (Hornbostel 1933: 299-301). A kelet-indiai Nálandá és Bhuvaneśvara városok szoborábrázolásain már a 6-8. század közötti időszakból ismertek a szabályozható membrános homokóra alakú dobtípusok (Kaufmann 1981: 176-77) (5. kép). Nyugat-Afrikához hasonlóan

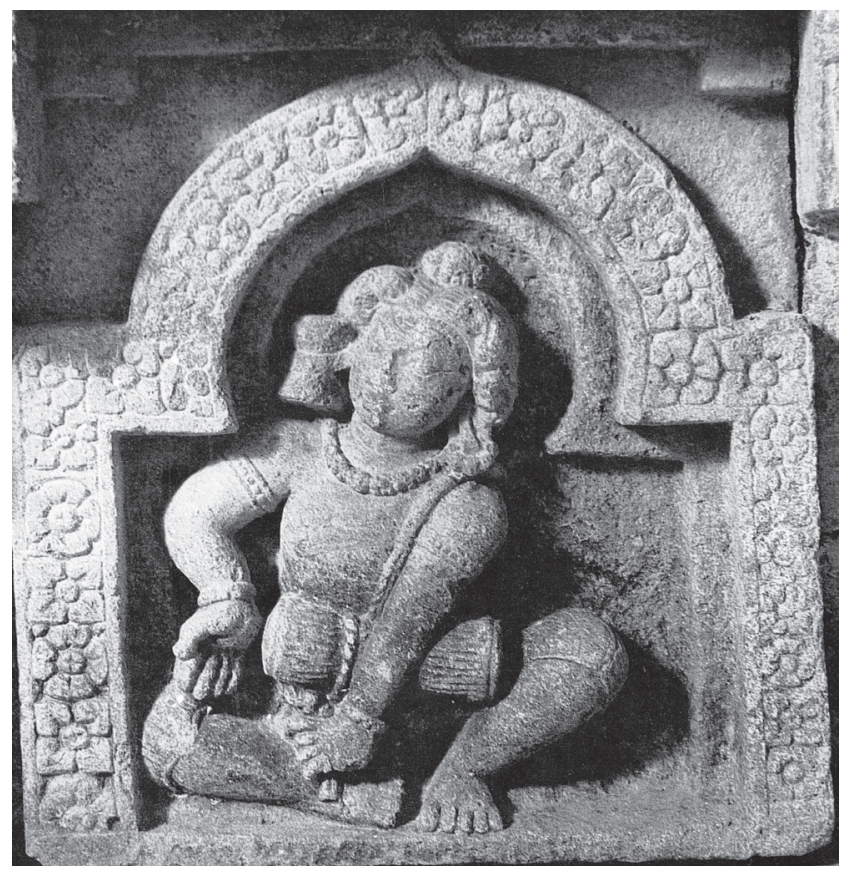

^5. kép. Panava homokóra dob 6-7. század India (Kaufman 1981 nyomán) 
Észak-Indiában szintén a szakmát generációról generációra öröklő, professzionális énekmondók használják a dhamu (damaru) szabályozható membrános homokóra alakú dobtípust, amit egyenesen Siva istenségtől származtatnak (Daniélou 1978: 88) (6. kép). A Dél-Indiában, leginkább Kerala tartományban elterjedt szabályozható membrános homokóra alakú dobtípus az edakka vagy idakka úgyszintén szakrális

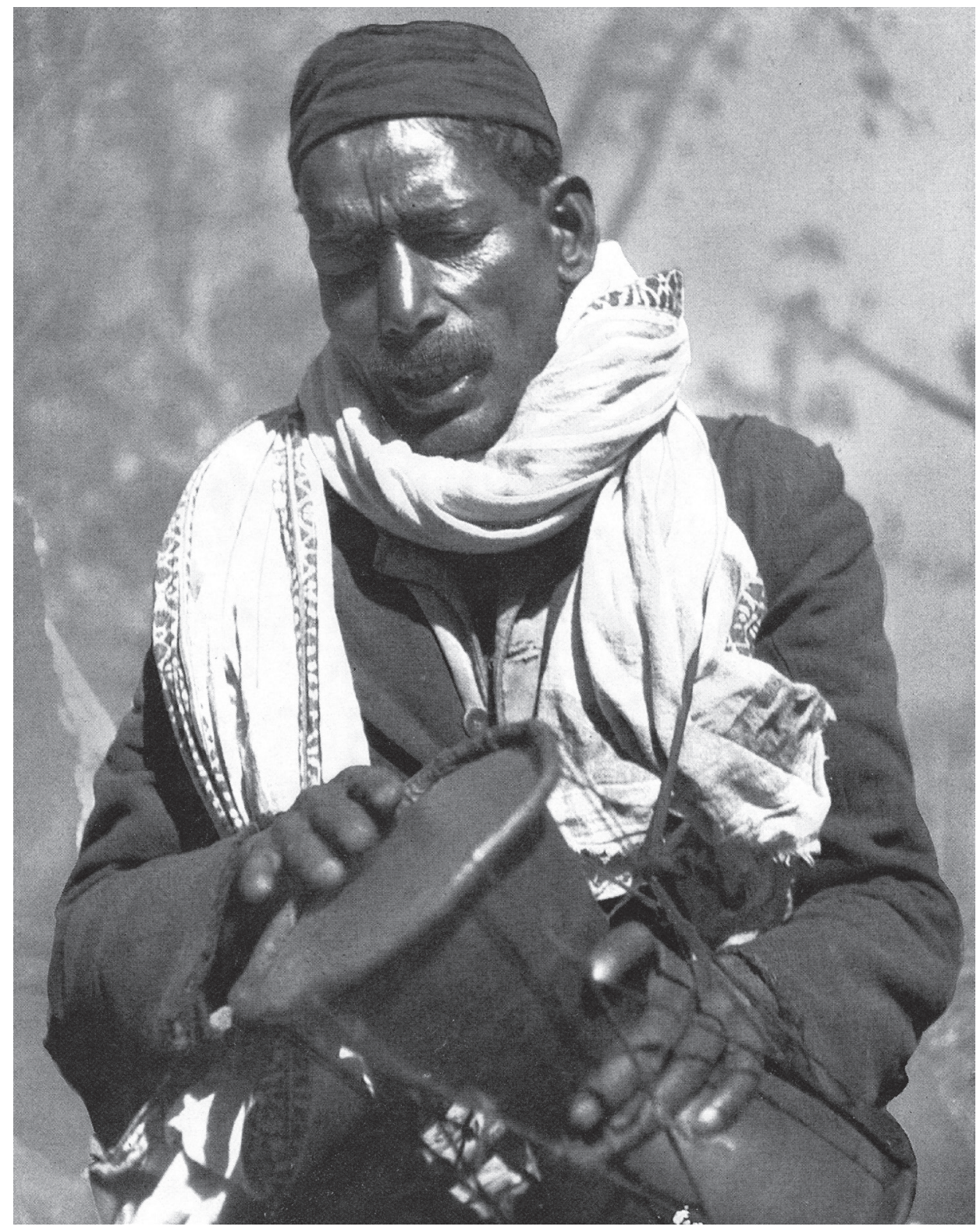

^ 6. kép. Dhamu homokóra dob India (Daniélou 1978 nyomán) 
hangszer, amelynek az elnevezése valószínűsíthetően a szanszkrít „dakka”, vagyis a 'hang' szóra vezethető vissza (7. kép). Mindezen hasonlóságok alapján felvetődött annak hipotézise, hogy valamikor a Kr.e. 2. században kapcsolat volt India és Afrika között és a nyugat-afrikai homokóradobok az ebben az időszakban megjelenő homokóradobok leszármazottai lennének (Marcel-Dubois - Auboyer 1941: 226). Az elmélet alátámasztására szolgálhat, hogy a mai Szudán északi részén található Meroé romjai reliefjeinek stílusa, illetve indiai elefántok ábrázolása szintén igazolni látszanak a kapcsolat lehetőségét (Arkell 1951: 57).

A membrán feszességét zsinórzattal szabályozható homokóra dobtípus onomatopoetikus (hangutánzó) elnevezései, szintén diffúz jellegü, interetnikus átvételeket sejtetnek, mint például az akan nyelvü népcsoportok körében a donno, a songhay nyelvüeknél doodo (NGDMI 1. 1984: 585), a manding (mande-tan) nyelvủeknél a djoungdjoung (NGDMI 1. 1984: 576) és a yoruba nyelvüeknél a dundun

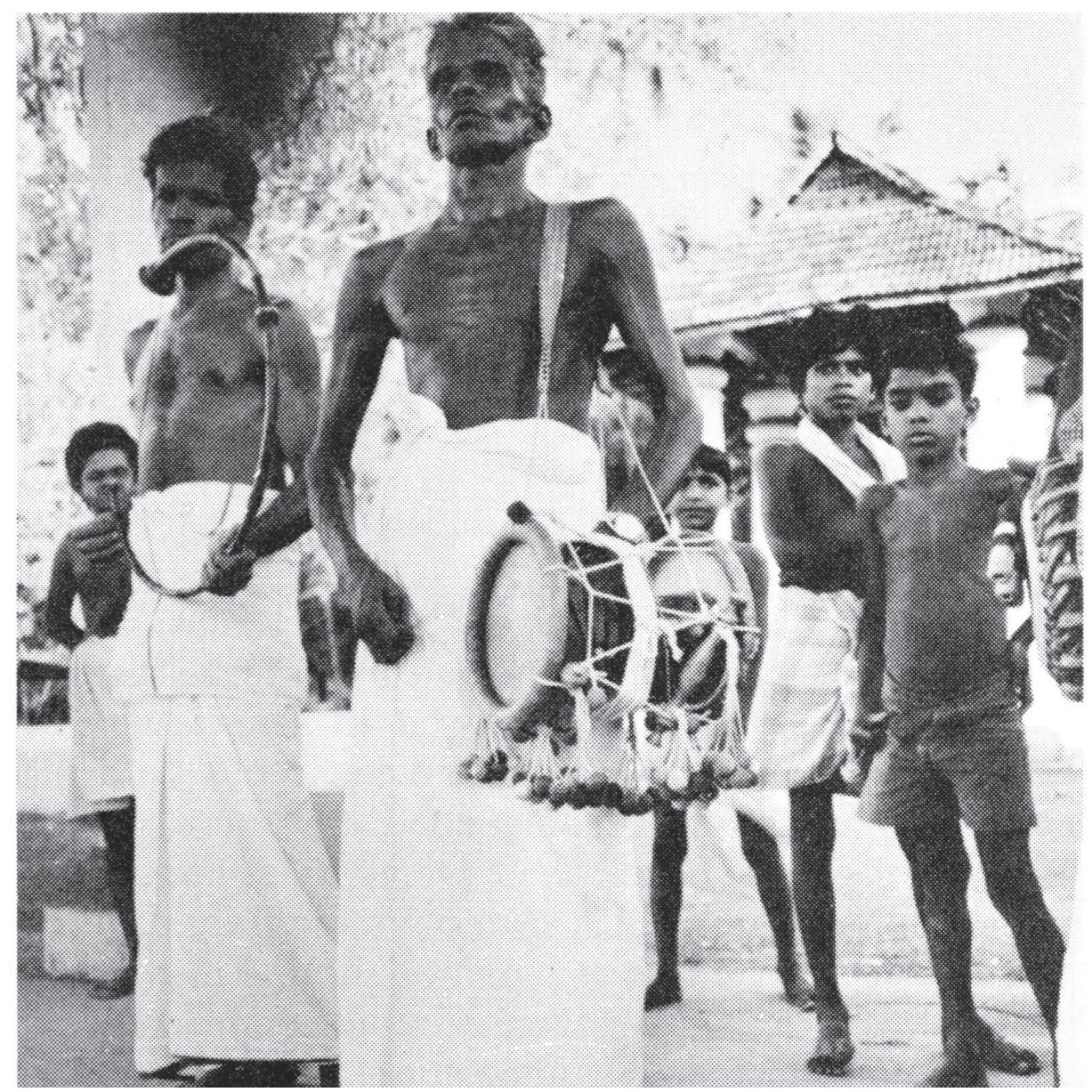

\7. kép. Idakka homokóra dob India (NGDMA 1984 nyomán) 
(NGDMI 1. 1984: 635). Ezzel szemben a hausa népcsoportnál kalangu vagy kalungu a hangszertípus elnevezése, míg a fulbe (fulani) népcsoportnál kalanggual (NGDMI 2. 1984:350). Szenegál, Gambia, Sierra Leone, Libéria és Elefántcsontpart területén kizárólag a wolof népcsoport körében elterjedt zsinórzattal szabályozható homokóra dobtípus a tama, amit a szomszédos manding (mande-fu) nyelvü népcsoportok is átvettek, mint a ma (mano) tama, a dan (gio) dama és a kpelle daning (NGDMI 3. 1984: 506).

A Nigéria délnyugati területén élö yoruba népcsoportnál a dundun típusú beszélő dobokon belül még hat altípust is megkülönböztetnek, úm. a legnagyobb az iya-ilu, ettől kisebb a kerikeri, a legkisebb a kanango és a közepes gangan (Simon 1983: 80-82). Illetve még egy gudu-gudu elnevezésủ edénydobot is társítanak hozzájuk. A yoruba Osun állam Ede uralkodójának (timi) udvari zenészei a dundun dobtípus iya-ilu 'anya-dob' nevü tagját közérdekủ történetek, hivatalos bejelentések és fontos személyeket dicsőitő versek (oriki) eljátszására alkalmazták (Kubik 1989: 98). A yoruba vallás spirituális elképzelései alapján az iya-ilu beszélő dob elkészítését szertartások előzik meg, mert a dobnak szánt fa kivágása előtt engesztelő áldozatot kell bemutatni, midőn a fa szelleme átköltözik a dob testébe. Mivel a fa szelleme beszél a dobban és ez a szellem viszont a bozóthoz kötődik, engesztelő áldozat hiányában a dob elnémulna (Ademole 1988: 19). Amennyiben az engesztelő áldozat sikeres, a fa szelleme a dob testébe költözik és a dobosok a dobolás által kapcsolatban állnak a fa szellemével. Ebből kifolyólag az ija-ilu dobokat rituális tisztelet övezi, mert minden dob egyben oltárnak is tekinthető. Az ija-ilu dobok használata napjainkban leginkább az 1920-as években kialakult Jùjú (dzsudzsu) könnyüzenei irányzatban él tovább és a többi, a membrán feszességét zsinórzattal szabályozható homokóra dobtípus is szerepet kapott a különböző nyugat-afrikai könnyüzenei irányzatban, mint a szintén nigériai gyökerü, az 1960-as években kialakult Fuji (fudzsi) és az 1970-es évek elején kialakuló szenegambiai Mbalax.

Összegzésként elmondható, hogy bár korábban az ún. beszélő dobok közös jellemzője eredetileg a kommunikációs funkciójuk volt, napjainkban a kortárs nyugat-afrikai világzenei produkcióiban, illetve az ún. afrobalettek kíséretében alkalmazzák. A történeti adatok áttekintése alapján a különböző népcsoportok vándorlásai és a dobtípusok összehasonlító elemzése arra enged következtetni, hogy valószínüleg az ún. stimulus diffúzió jelenségével magyarázható a beszélő dobok nyugat-afrikai elterjedése és eredetileg valahonnan a Szaharától északra eső területről származhat a hangszertípus alapötlete, amelynek eredete nem kizárt, hogy egy indiai dobtípusra vezethető vissza. Az adatok összevetése a szintén kommunikációs funkciójú résdobokkal arra enged következtetni, hogy amíg a nyugat-afrikai membranofon rendszerủ beszélő dobtípusok a beszélt nyelvet képezték le, addig a Kelet- és Közép-Afrikában elterjedt idiofon rendszerü résdobokat eredetileg egy fogalom rendszerü üzenetközvetítésre használhatták és a két rendszer egymásra hatásaként terjedhettek el a résdob-használó népcsoportok körében is a beszélt nyelvet imitáló dobnyelvek. Napjainkra a résdoboktól eltérően a beszélő dobtípusok sokkal inkább fennmaradtak, ami annak köszönhető, hogy a nyugat-afrikai régió autentikus 
zeneformái könnyűzenei stílussá alakulva nemcsak a régióban élnek tovább, de a nyugati világ zenei rendezvényein és zeneiparában is kedvező fogadtatásra találtak. Ezért hírközlő funkciójukat elveszítve, viszont zenei kíséret szerepkörben nemcsak az eredeti közegükben, de a különböző világzenei fesztiválok egzotikus hangszereként is tovább élnek. Ezen túlmenően a hangszertípus kortárs zenei kultúrában való népszerüsítéséhez nagyban hozzájárult, hogy Bill Kreutzmann, a Grateful Dead dobosa alkalmanként beszélő dobon játszott a zenekar koncertjein. Szimbolikus „afrikai hangszerként” a Marvel képregényen alapuló, 2018-ban bemutatott „Fekete párduc" címü szuperhős mozifilmben is kiemelt szerepet kapott.

\section{Jegyzetek}

1 Tekintve hogy nagyon sok afrikai hangszer és népcsoport elnevezésnek nincs magyar megfelelöje, az afrikai hangszerelnevezéseknél a The New Grove Dictionary of Musical Instruments terminusai, és az afrikai népcsoportok elnevezéseinél a The Peoples of Africa. An Ethnohistorical Dictionary az irányadó.

2 NMAGy ltsz: 103462

3 NMAGy ltsz: 53.21.15; WWAsS ltsz: 085087; 118836; 127519; 141369;

4 WWAsS ltsz: 056976

5 NMAGy ltsz: $135372 ; 135373 ; 135375$;

6 WWAsS 1tsz: 075501; 075502; 075503; 075504;

7 NMAGy ltsz: 25443

8 WWAsS ltsz: 122664

9 Russel Cotes Art Gallery and Museum, ltsz: RH46; Powel Cotton Museum, ltsz: ETH. JARVIS. 16

\section{Felhasznált irodalom}

- ADEMOLE, Adegbite (1988): The Drum and Its Role in Yoruba Religion. Journal of Religion in Africa, Vol. 18, Fasc. 1, pp. 15-26.

- AKPABOT, Samuel (1975): The Talking Drums of Nigeria. African Music Society Journal Vol. 5, No. 4, pp. 36-40.

- ALAGOA, Ebiegberi Joe - ANOZIE, F. N. - NZEWUNWA, Nwanna szerk. (1988):

- The early history of the Niger Delta. Hamburg: H. Buske

- ARKELL, Anthony John (1951): Meroe and India. Aspects of Archeology in Great Britain and Beyond. London 32-38.

- BRAUER-BENKE József (2018): Az afrikai tamtam-ok avagy résdobok története és típusai.

- Afrika Tanulmányok 12:(1-3) pp. 137-156.

- BUSNEL, René-Guy - CLASSE, André (1976): Whistled Languages. New York: SpringerVerlag.

- CARRINGTON, John F. (1949): Talking drums of Africa. London: Carey Kingsgate Press.

- CHARRY, Eric S. (2000): Mande Music: Traditional and Modern Music of the Maninka and Mandinka of Western Africa. Chicago: University of Chicago Press

- CLARKE, Roger T. (1934): The Drum Language of the Tumba People. American Journal of Sociology. Vol. XL. 34-48.

- DANIÉLOU, Alain (1978): Südasien. Musikgeschichte in Bildern, Bd.1.Lfg.4. Leipzig:

- Deutcher Verlag für Musik Leipzig

- FRIEDLÄNDER, Marianne (1992): Lehrbuch des Malinke. Langenscheidt Verlag Enzyklopädie 
- HALE, Thomas A. (1997): From the Griot of Roots to the Roots of Griot: A New Look at the Origins of a Controversial African Term for Bard. Oral Tradition 12:(2) pp. 249-278

- HERZOG, George (1934): Speech Melody and Primitive Music. Musical Quarterly Volume XX, Issue 4, 1 October, pp: 452-466.

- HORNBOSTEL, Erich Moritz von (1933): „Zum Kongreß für arabische Musik - Kairo 1932”, Zeitschrift für vergleichende Musikwissenschaft Berlin 1,16-17.

- JONES, Arthur Morris (1964): Africa and Indonesia. The Evidence of the Xylophone and Other Musical and Cultural Factors. Leiden: Brill

- KAUFMANN, Walter (1981): Altindien. Musikgeschichte in Bildern, Bd.2.Lfg.8. Leipzig: Deutscher Verlag für Musik Leipzig

- KESZTHELYI Tibor (1980): Az afrikai dobnyelv mint a költői közlés eszköze. In: KÓSA László (szerk.), Népi kultúra-népi társadalom, 11-12: 579-589. Budapest: Akadémiai Kiadó

- KUBIK, Gerhard (1989): Westafrika. Musikgeschichte in Bildern, Bd.1.Lfg.11. Leipzig: Deutscher Verlag für Musik Leipzig

- KYEREMATEN, Alex Atta-Yaw (1964): Panoply of Ghana. London: Longmans

- MARCEL-DUBOIS, Claudie - AUBOYER, Jeannine (1941): Les Instruments de musique de l'Inde ancienne. Paris: Presses universitaires de France

- MARCUSE, Sybil (1975): A Survey of Musical Instruments. New York: Harper\&Row

- McCALL, Daniel F (2008): Afrikan weeks. In: In Hot Pursuit of Language in Prehistory: Essays in the four fields of anthropology. In honor of Harold Crane Fleming. John D. Bengtson (ed). John Benjamins Publishing Company, 25-36.

BENGSTON, John D-FLEMING, Harold Crane (szerk) 25-39. Amsterdam-Philadelphia

- NGDMI-The New Grove Dictionary of Musical Instruments (1984): Szerk. SADIE, Stanley I-III. London: Macmillen Publishers Limited

- NKEITA, Joseph Hanson Kwabena (1966): Ayan: the poetry of the Atumpan dums of the Asantehene. University of Ghana: Institute of African Studies

- ONG, Walter J. (1977): African Talking Drums and Oral Noetics. New Literary History, 8/3, 411-429.

- OLSON, James S. (1996): The Peoples of Africa: An Ethnohistorical Dictionary. Westport, Connecticut-London: Greenwood

- PANTALEONI, Hewitt (1972): Three principles of timing in anlo dance drumming. African Music Society Journal, Grahamstowne 5/2.50-63.

- SIMON, Artur (1983): Musik in Afrika. Mit 20 Beiträgen zur Kenntnis traditioneller afrikanischer Musikkulturen. Berlin: Museum Für Völkerkunde. 


\section{English Abstract}

\section{African Talking Drums}

An overview of the available historical data regarding the so-called "talking drums" leads to the general conclusion that their most prominent shared feature is their original use for communication. On the grounds of the migrations of various ethnic groups and the comparison of the different types of drums, a likely explanation for the distribution over West Africa of these drums must be sought in the phenomenon of the so-called stimulus diffusion, and the basic idea behind such instruments must originate in the region north of the Sahara; it is also possible that the origin of such instruments can be traced back to an Indian drum type. A comparison of the relevant data with the slitdrums, which also serve for communicative purposes, allows one to conclude that the membranophonic talking drums of West Africa mimicked the sounds of spoken language, while the idiophonic slitdrums of East and Central Africa must have originally been used for a concept-based coding of messages. It is the interaction of the two systems of communication that must have led to the diffusion of drum languages imitating the spoken languages among the ethnic groups using slitdrums. Unlike slitdrums, the various types of talking drums have proven quite resilient. Their survival is due to the tendency of the authentic musical traditions of the West African region to be transformed into popular music styles and thereby perpetuate themselves not only within the region but also at musical events and the music industry of the West, where they find an appreciative audience. Having lost their communicative function and acquired a new role as musical accompaniment, they survive in their natural environment as well as in the role of exotic instruments at various world music festivals.

\section{A szerzörő}

PhD, tudományos munkatárs

MTA BTK Zenetudományi

Intézet

About the Author

$\mathrm{PhD}$, Ethno-organologist

Institute for Musicology,

Research Center for the

Humanities, Hungarian

Academy of Sciences

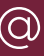

braver-benke.jozsef@btk.mta.hu 


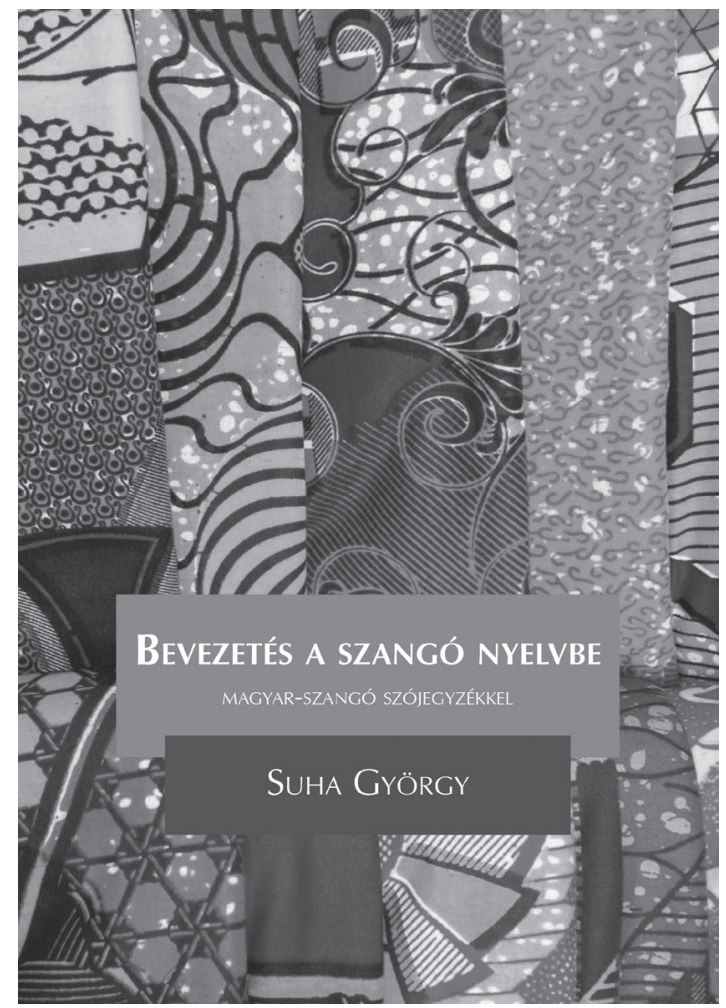

\title{
SUHA GYÖRGY
}

\section{BEVEZETÉS A SZANGÓ NYELVBE}

\author{
MAGYAR-SZANGÓ SZÓJEGYZÉKKEL
}

Ez a rövid áttekintés magyar nyelven elöszőr, a szakirodalom bemutatásával, egyfajta nyelvkönyvként, segédkönyvként, szótárként segíti a szangó nyelv, vagy általában az afrikai nyelvek iránt érdeklődóket.

Az elmúlt évtizedben Magyarországon lendületet kapott afrikanisztikai kutatások társadalom- és gazdaságtudományi dimenziói érdemben járultak hozzá a kontinensen zajló folyamatok megértéséhez és a magyar kutatók-oktatók lelkesedése számos, néhány évvel korábban szinte elképzelhetetlen kezdeményezést is útjára indíthatott. Egy ilyen szakmai kísérlet eredményét tartja kezében a Tisztelt Olvasó.

Jelen kiadványunk magyar-szangó szótára hozzávetôlegesen 1100 elemból áll, de a szókészlet összeállításakor igyekeztünk ismeretterjesztô és gyakorlatias szempontokat egyaránt figyelembe venni. 